\title{
A COMPARATIVE RESEARCH BETWEEN EXTROVERT AND INTROVERT PERSONALITY ON SPEAKING ACHIEVEMENT
}

\author{
$1^{\text {st }}$ Intan Nur Ahmar \\ English Education Department \\ Universitas Panca Sakti Bekasi \\ intan.nurahmar2309@gmail.com
}

\author{
$2^{\text {nd }}$ Sugiyanta \\ English Education Department \\ Universitas Panca Sakti Bekasi \\ Sugiyanta2711@gmail.com
}

\begin{abstract}
Speaking is a productive skill that can be immediately observed. The major goal of all English language teaching should be to provide learners with the ability to use English effectively and accurately to achieve better communication. However, some students still have difficulty in speaking, because of their different performance levels. They process information differently and there is a difference in personality (extrovert and introvert). This current research is to investigate whether there is a significant difference between introvert and extrovert students on their speaking achievement at Cambridge School of English. 23 students were selected as the sample and their personality type was determined by using Eysenck Personality Questionnaire and their speaking score from the speaking test. This research was quantitative approach; a nonexperimental research design. The result of the research reveals that there is a different mean score between the extrovert and introvert students although the difference is slight, the mean score of the extrovert students is 74 and introvert students is 76,54. Meanwhile by collecting numerical data analyzed using SPSS 22 , the result of the independent sample $t$-test shows that the $t$-table is higher than $t$-count $(-1.360<t$-table 1.721$)$, therefore $\mathrm{H}_{0}$ is accepted and $\mathrm{Ha}$ is rejected. It means that there is no significant difference between extrovert and introvert students in speaking achievement.
\end{abstract}

Keywords: Comparative research; extrovert personality; introvert personality; speaking achievement.

\section{INTRODUCTION}

Speaking seems to be the most important skill of all the four skills (listening, speaking, reading, and writing) because people who know a language are usually referred to as speakers of that language (Ur as cited inTuan and Mai, 2015). The main goal of English language teaching should be to provide learners with the aptitude to use English successfuly and accurately to achieve better performance in communication. However, not all language learners after many years of researching English can interact and communicate fluently and accurately as they lack the necessary knowledge.

Many factors affect the success in speaking performance. Some of them are gender, intelligence, age, language aptitude, motivations, preferred learning styles and strategies, and the learner's attitudes and beliefs. One of the main factors is also personality or character. According to Wright and Taylor (1970), a character refers to the ones exceedingly solid and enduring factors of the character which distinguish him from different people, and on the identical time from the premise of our predictions regarding his destiny conduct. Another definition that captures an awful lot of what psychologists suggest via way of means of character is Child's (1968) description of character traits as greater or much less solid inner elements that make one person's conduct regular from one time to any other and from one scenario to any other. Personality, as Peterson (1992) says, has the subsequent features:

a. It is an incorporated a part of a character - something someone is, does, or has. People carry their personalities to conditions and take them once they leave. b. It is mental- refers back to the character's actions, mind and emotions and now no longer fabric matters along with possessions and status.

c. It is made of smaller devices known as traits- the aggregate of those traits creates 
a unique mental signature.

Furthermore, findings of some studies that check out persona trends are primarily based totally on the assumptions that inexperienced persons deliver to the schoolroom now no longer most effective their cognitive abilities, however, additionally powerful states which affect the manner they gather the language. Extrovert and introvert are two personality traits that influence speaking performance has been the most frequently checked. Brown (2000) lists self-esteem, inhabitation, risk-taking, anxiety, empathy, and extroversion as persona factors. Many language acquisition theories declare that extroverts are the higher language inexperienced persons given that they tend to be sociable, much more likely to enroll in companies and greater willingness to have interaction in conversations each inside and out of doors the schoolroom (Swain, 1985). Likewise, Naiman, Frohlick, Stern, and Todesco (1978) accept as true that extrovert who're sociable and open to different human beings are greater a hit in gaining knowledge of languages than introverts. Swain and Burnaby (1976); however, accept as true that wellprepared and severe introverts are visible higher inexperienced persons at some distance because the systematic observe is concerned.

According to Jung (1971), there are forms of persona they may be extrovert persona and introvert persona. he says that extrovert is sort of humans whose interests is directed out of doors himself. Whereas introvert kind belongs to humans whose interest are centered on themselves this is towards his ego.

In addition, Vogel and Vogel (1986) additionally located that extrovert college students acquire more fluency in an oral manufacturing project in comparison to introverts.

Eysenck (1964) states that extrovert students are talkative, peevish, and outgoing in their communication, and introvert students are reserved, quiet, and peaceful. They are sociable, easy-going, have many friends, need enjoyment, and tend to be enterprising and a risk-taker, whereas a highly introverted person, is motionless, retiring, and introspective, and seldom behaves aggressively. A widelyheld belief in the language pedagogy community is that extroverts are more likely to perform better in second language use and communication situations.

Further, Wulandari et al, (2017) conducted research entitled "Extrovert and Introvert Students in Speaking Ability of English Department at IAIN Palangka Raya". The design of this research used a quantitative approach; ex post facto design. This research was intended at exploring whether there is a significant difference between an introvert and extrovert and students in speaking performance of English Department at IAIN Palangka Raya. To collected the data, the researchers used a questionnaire and documentation as the instruments. The result of the research showed that the alternative hypothesis $(\mathrm{Ha})$ was accepted and the null hypothesis (Ho) was rejected. In conclusion, there is a significance difference between extrovert and introvert students in the speaking ability of the English Department at IAIN Palangka Raya.

Chen et. al (2015) did a study entitled A Survey Study: The Correlation among Introversion/Extroversion and Oral English Learning Outcome located that the 2 variables aren't correlated (college students' persona and talking ability haven't any sizeable relationship).

As Nadiyah (2010) did a study entitled Comparative Analysis on Choleric Students and Melancholic Students Concerning Their English-Speaking Skill. The result states that the college students' English persona distinction has no statistically sizeable distinction to the college students' English competence. Both institutions of college students might also additionally carry out higher English talking ability thru their manner of 
learning. It way that scholars with extrovert and introvert persona generally tend to have exact success in talking overall performance too.

This current research is to investigate whether there is a significant difference between introvert and extrovert students in their speaking achievement at Cambridge School of English. It seeks to answer the following research questions: (1) How is the extrovert students' speaking performance at Cambridge School of English? (2) How is the introvert students' speaking performance at Cambridge School of English? and (3) Is there any significant difference between the extrovert and the introvert students in their speaking performance at Cambridge School of English?

\section{METHOD}

This current research was conducted at the Cambridge School of English (March-June 2021). Cambridge School of English is one of the English courses in Bekasi. This course is conducted twice a week for each class, with 90 minutes for every meeting which means 180 minutes in a week. In the course, the speaking skill is implemented in a dialog method and giving a speech. The students are expected to achieve better performance, that is to be able to make dialogs and practices, to understand expressions appropriate to the context and others. The rated aspects of speaking performance are pronunciation, clarity, accuracy, performance skill, and fluency.

The population of the research was all the students in Cambridge School of English. The total number of students was 23 students that came from six classes, consisting of Starter 2, Upper Starter 1, Upper Starter 3, Pre-Elementary 4, Elementary 2, and conversation class. Then, the sample in this research was 23 students. Researchers used a random sampling technique.

To gather the data for this research, the researchers used an oral test, but before that, the researchers used a google form to share the questionnaire to measure the student's personality. The questionnaire consisted of 24 questions, developed from indicators of extrovert and introvert, and the questions adopted from the Eysenck Personality Inventory.

The researchers followed some procedures before doing the test. In the first meeting, the researchers explained the material related to recounting text, such as:/ the grammar used in the text and structure of the text. The researchers also requested the students to create their recount text and the topic was related to their experience and after that, the writers asked the students to deliver their recount text about their experience.

To find out if there is a significant disparity in students speaking performance among extroverts and introverts, the researcher analyzed it by utilized the statistic software Statistical Product and Service Solutions (SPSS) 22.00.

\section{RESULTS AND DISCUSSION Eysenck Personality Inventory}

The Eysenck Personality Inventory (EPI) measures two pervasive, independent standards of personality, ExtraversionIntroversion, and Neuroticism-Stability, which account for most of the variance in the individuality domain. Each form contains 57 "Yes-No" items with no rehash of items. There are 24 items for measuring extrovert-introvert levels.

The result of the items is interpreted using an $\mathrm{E}$ score in Eysenck Personality Inventory. Based on the personality measurement of the Eysenck Personality Inventory, if the respondents get 0-12 E score, they are categorized as an introvert, and if the respondents get 13$24 \mathrm{E}$ score, they are categorized as an extrovert.

\section{Validity Validity of The Questionnaire}

To interpret the validity of the questionnaire, the writer arranged a try-out of 24 items by delivering them to 20 
students who are incorporated in the research specimen. The researchers applied SPSS 22 program to analyze the data.

The researchers compared $\mathrm{r}$-item to $\mathrm{r}$ table at a valuable level of $5 \%$ is 0,444 $(\mathrm{N}=20)$. The standard value of validity is $\mathrm{r}^{-}$-item $>\mathrm{r}^{-}$table. Based on the try-out proceeds, it was specified that there are invalid items. The result of try out is as follows:

Table 1. The Validity of Questionnaire

\begin{tabular}{llll} 
Item & r-item & r-table & Result \\
\hline $\mathbf{1}$ & 0.336 & 0.444 & Invalid \\
$\mathbf{2}$ & 0.65 & 0.444 & Valid \\
$\mathbf{3}$ & 0.311 & 0.444 & Invalid \\
$\mathbf{4}$ & 0.537 & 0.444 & Valid \\
$\mathbf{5}$ & 0.495 & 0.444 & Valid \\
$\mathbf{6}$ & 0.479 & 0.444 & Valid \\
$\mathbf{7}$ & 0.32 & 0.444 & Invalid \\
$\mathbf{8}$ & 0.211 & 0.444 & Invalid \\
$\mathbf{9}$ & 1 & 0.444 & Valid \\
$\mathbf{1 0}$ & -0.104 & 0.444 & Invalid \\
$\mathbf{1 1}$ & 0.304 & 0.444 & Invalid \\
$\mathbf{1 2}$ & 0.735 & 0.444 & Valid \\
$\mathbf{1 3}$ & 0.537 & 0.444 & Valid \\
$\mathbf{1 4}$ & 0.369 & 0.444 & Invalid \\
$\mathbf{1 5}$ & 0.305 & 0.444 & Invalid \\
$\mathbf{1 6}$ & -0.058 & 0.444 & Invalid \\
$\mathbf{1 7}$ & 0.421 & 0.444 & Invalid \\
$\mathbf{1 8}$ & 0.272 & 0.444 & Invalid \\
$\mathbf{1 9}$ & 0.393 & 0.444 & Invalid \\
$\mathbf{2 0}$ & 0.141 & 0.444 & Invalid \\
$\mathbf{2 1}$ & 0.176 & 0.444 & Invalid \\
$\mathbf{2 2}$ & 0.537 & 0.444 & Valid \\
$\mathbf{2 3}$ & 0.141 & 0.444 & Invalid \\
$\mathbf{2 4}$ & 1 & 0.444 & Valid \\
\hline
\end{tabular}

\section{Validity of The Test}

In this research, the researcher applied content validity to find out the validity of the speaking test. The test has content validity in case the test is suitable with the studies that are taught in the class.

\section{Reliability}

Reliability has to do with the accuracy of metering. This kind of exactness was described in acquiring coincident results when the measurement was restated on different or by a dissimilar person.

\section{Reliability of The Questionnaire}

To discovered the reliability of the questionnaire, the researchers applied the SPSS 22.00 version and the table of reliability level to know the reliability level of this research.

Table 2. The level of Acceptable Reliability

\begin{tabular}{ccc} 
NO & Reliability & Validity \\
\hline 1 & $>0.90$ & Very high \\
2 & $0.80-0.90$ & High \\
3 & $0.70-0.79$ & Reliable \\
4 & $0.60-0.69$ & Marginally Reliable \\
5 & $<0.60$ & Unacceptably low \\
\hline
\end{tabular}

(Cohen,Manion,\& Morison,2007:506)

Table 3. Reliability Statistic

\begin{tabular}{ll}
$\begin{array}{l}\text { Cronbach's } \\
\text { Alpha }\end{array}$ & N of Items \\
\hline .685 & 25 \\
\hline
\end{tabular}

Based on the previous data, it could be seen that the value of Cronbach's alpha was 0.685 . It showed that the items were marginally reliable, where the value of internal consistency was $0.60<0.685$, therefore the test was marginally reliable.

\section{Findings}

After distributing the questionnaire, the researchers know which student is extrovert or introvert. Then, to get more valid data about extrovert and introvert students in public speaking class, the researchers joined the class final test on Monday, Tuesday, Wednesday, Thursday, Friday and Saturday $7^{\text {th }}-12^{\text {th }}$ June 2021 to watch the student's performance and recognize the student's personality, the researcher joined 12 meetings in two weeks on Monday, Tuesday, Wednesday, Thursday, Friday and Saturday and watch every students performance to understand their personality and their performance in front of the class.

The researchers distributed the questionnaire to 23 students from six 
classes and divided them into two groups extroverts and introverts based on the questionnaire they have already answered. For more detailed information, the data can be seen in table 3 .

Table 4. Result of Extrovert and Introvert Questionnaire

\begin{tabular}{|c|c|c|c|}
\hline \multirow{2}{*}{ No } & \multirow{2}{*}{ Student } & \multicolumn{2}{|c|}{ Score } \\
\hline & & Extrovert & Introvert \\
\hline 1 & ODS. & 15 & 9 \\
\hline 2 & MP & 21 & 2 \\
\hline 3 & BKP & 7 & 17 \\
\hline 4 & TAF & 17 & 7 \\
\hline 5 & NHM & 11 & 13 \\
\hline 6 & NS & 10 & 14 \\
\hline 7 & K & 9 & 15 \\
\hline 8 & ATO & 13 & 11 \\
\hline 9 & BA & 16 & 8 \\
\hline 10 & LS & 14 & 10 \\
\hline 11 & FDJ & 12 & 12 \\
\hline 12 & IKZ & 12 & 12 \\
\hline 13 & MWC & 8 & 16 \\
\hline 14 & RN & 16 & 8 \\
\hline 15 & MBC & 15 & 9 \\
\hline 16 & WA & 4 & 20 \\
\hline 17 & $\mathrm{CV}$ & 17 & 7 \\
\hline 18 & AR & 9 & 15 \\
\hline 19 & $\mathrm{AH}$ & 12 & 12 \\
\hline 20 & FRA & 12 & 12 \\
\hline 21 & VAF & 7 & 17 \\
\hline 22 & GI & 13 & 11 \\
\hline 23 & $\mathrm{KAl}$ & 7 & 17 \\
\hline & TOTAL & 275 & 264 \\
\hline
\end{tabular}

Table 4 shows that the scores of the extroverts and introvert students in class. Students with the highest score in questions of extroverts showed they are extrovert students or vice versa.

Those who are extroverts will answer yes to question $1,2,4,5,6,8,13,14$, $15,17,19,20,21,23$, and 24 , the introverts will answer yes to question number 3, 7,9, $10,11,12,16,18$, and 22 the questions are related to the extrovert and introvert aspects of personality.

\section{Description of extrovert students in the Class}

10 students are extroverts in the class. It is concluded based on the result of their answer to the questionnaire. The detailed data about the final score of extrovert students in the class can be seen in the following table 5 .

Table 5. The Result of Final Score of Extrovert Students

\begin{tabular}{clc} 
& & FINAL \\
NO & EXTROVERT & SCORE \\
\hline 1 & ODS & 70 \\
2 & MPS & 72 \\
3 & TAF & 70 \\
4 & ATO & 68 \\
5 & BAP & 82 \\
6 & LS & 80 \\
7 & CV & 74 \\
8 & RN & 70 \\
9 & GIA & 80 \\
10 & MBC & 74 \\
\multicolumn{2}{c}{ TOTAL } & 740 \\
\hline
\end{tabular}

Based on table 5, shows the score of extrovert students are 740 , to better understand the mean of score middle test speaking the writer uses the formula as follows:

$$
\begin{gathered}
M=\frac{\sum X}{N} \\
M=\frac{740}{10}=74
\end{gathered}
$$

Based on the result of the applied formula above, the total score ofextrovert students is 740 of 10 students, and the mean score is 74 .

Table 6. The frequency distribution of the speaking ability and category of extrovert

\begin{tabular}{|c|c|c|c|c|}
\hline No & Score & Category & Student & $\%$ \\
\hline 1 & $85-<100$ & Excellent & 0 & $0 \%$ \\
\hline 2 & $70-<85$ & Good & 9 & $90 \%$ \\
\hline 3 & $60-<70$ & Fair & 1 & $10 \%$ \\
\hline 4 & $40-<60$ & Low & 0 & $0 \%$ \\
\hline 5 & $0<40$ & Very low & 0 & $0 \%$ \\
\hline
\end{tabular}
students

Table 5 shows that the result of the final score students' extrovert on Cambridge 
School of English. Based on the result, there are 9 students (90\%) getting the score of 70-185 (good category), 1 student $(10 \%)$ getting the score of $60-<70$ (fair category), there is no student in the excellent, low and very low category.

\section{Description About Introvert students in the class}

13 students are introverted in the class. It is concluded based on the result of their answer to the questionnaire. The detailed data of the final score of introverted students in the class can be seen in the following table 7 .

Table 7. The Result of Final Score of Introvert Students

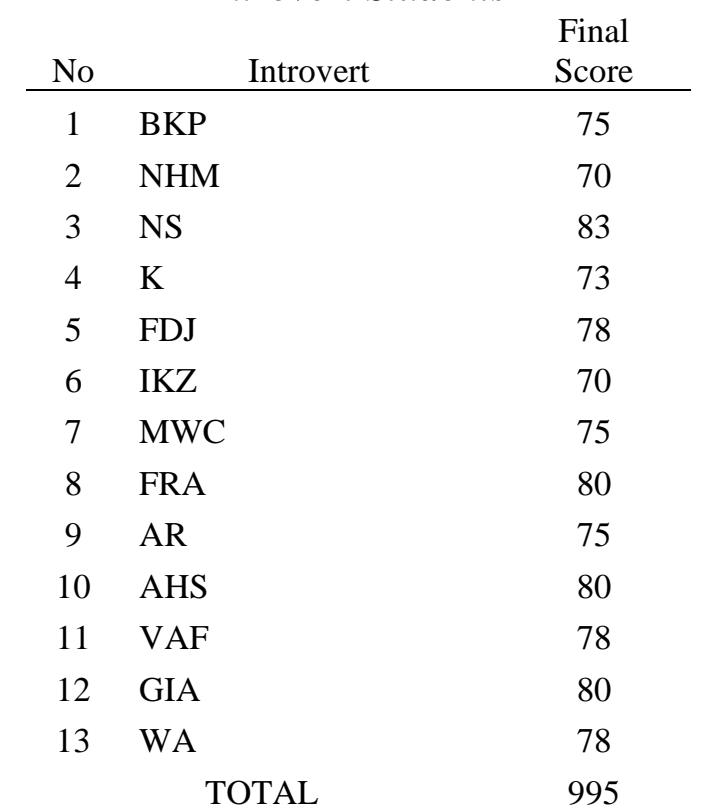

The accumulated score of introvert students is 995 to better understand the mean of score final test speaking the researcher uses the formula as follows:

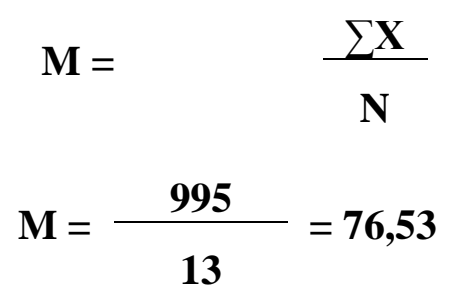

Based on the result of the applied formula above, the total score ofextrovert students is 995 of 13 students, and the mean score is 76.53 .
Table 8. The frequency distribution of the speaking ability and category of introvert students

\begin{tabular}{ccccl}
$\mathrm{N}$ & & & Total Of \\
$\mathrm{O}$ & Score & Category & Students & $\%$ \\
\hline 1 & $85-<100$ & Excellent & 0 & $0 \%$ \\
2 & $70-<85$ & Good & 13 & $100 \%$ \\
3 & $60-<70$ & Fair & 0 & $0 \%$ \\
4 & $40-<60$ & Low & 0 & $0 \%$ \\
5 & $0<40$ & Very low & 0 & $0 \%$ \\
& & Total & & $\mathbf{1 0 0 \%}$ \\
\hline
\end{tabular}

Table 8 shows that the result of the final score of introvert students at Cambridge School of English class. Based on the result, there were 13 students (100\%) getting a score of 70-85 (good category), there was no student in the excellent category, fair category, low category, and very low category.

\section{The difference between extrovert and introvert student's score}

To compare the students who are extroverts and introverts on public speaking, the researchers use SPSS 22. After all the collected were processed, the writer analyzed them and concluded by using the independent sample T-test method.

Before doing the independent sample t-test the researchers tested the data using normality test to assure the data is normal using SPSS 22 software and the result can be seen in the following table 8 .

Table 9. Test of Normality

One-Sample Kolmogorov-Smirnov Test

\begin{tabular}{|c|c|c|c|}
\hline & & Extrovert & Introvert \\
\hline $\mathrm{N}$ & & 10 & 13 \\
\hline Normal & Mean & 74.00 & 76.54 \\
\hline Parameters ${ }^{a, b}$ & $\begin{array}{l}\text { Std. } \\
\text { Deviation }\end{array}$ & 4.989 & 3.971 \\
\hline Most Extrem & eAbsolute & .200 & .182 \\
\hline Differences & $\begin{array}{l}\text { Positive } \\
\text { Negative }\end{array}$ & $\begin{array}{l}.200 \\
-.185\end{array}$ & $\begin{array}{l}.115 \\
-.182\end{array}$ \\
\hline $\begin{array}{l}\text { Test Statistic } \\
\text { Asymp. Sig. ( }\end{array}$ & (2-tailed) & $\begin{array}{l}.200 \\
.200^{\mathrm{c}, \mathrm{d}}\end{array}$ & $\begin{array}{l}.182 \\
.200^{\mathrm{c}, \mathrm{d}}\end{array}$ \\
\hline
\end{tabular}


a. Test distribution is Normal.

b. Calculated from data.

c. Lilliefors Significance Correction.

d. This is a lower bound of the true significance.

From table 9 the significant values are $0,200>0,05$. It can be concluded that the data of extrovert and introvert students are normal.

After doing the normality test the researchers test the data using homogeneity test to assure the data is homogenous, the result is:

Table 10. Test of Homogeneity of Variance

Levene

\begin{tabular}{llll} 
Statistic & df1 & df2 & Sig. \\
\hline .558 & 1 & 21 & .463 \\
\hline
\end{tabular}

From the table 10 the significant value based on mean are $0,463>0,05$. it can be concluded that the extrovert and introvert groups are homogenous or in the same variant.

a. The result indicates that the data is normal and homogenous, the next step was to do the independent sample t-test, and the result can be seen in the following table.

Table 11. Independent Samples Test

Levene's Test for

Equality of

Variances t-test for Equality of Means

95\% Confidence

Mean Std. ErrorInterval of the

\begin{tabular}{|c|c|c|c|c|c|c|c|}
\hline $\mathrm{F}$ & Sig. & df & tailed) & $\mathrm{e}$ & e & Lower & Upper \\
\hline $\begin{array}{l}\text { Nilai Equal variances } \\
\text { Spea assumed }\end{array}$ & .463 & -1.36021 & .188 & -2.538 & 1.866 & -6.419 & 1.342 \\
\hline $\begin{array}{c}\text { king Equal variances } \\
\text { not assumed }\end{array}$ & & -1.31916 & 0.205 & -2.538 & 1.924 & -6.600 & 1.523 \\
\hline
\end{tabular}

From table 11 the researcher found the tcount is $-1.360 \mathrm{df}$ (degrees of freedom) in this research is 21 .

b. T-test

For the data are normal and homogeneous, calculations t-test can be done. Based on the results of the calculations are obtained $\mathrm{t}$-count is -1.360 and the df (degrees of freedom) is 21 and from the $\mathrm{t}$-table, it can be seen that the $\mathrm{t}$-count is $-1.360<\mathrm{t}$ table 1.721.

Because of $\mathrm{t}_{\text {-table }}<\mathrm{t}$-count, therefore $\mathrm{H} 0$ (there is no significant difference between extrovert and introvert students speaking performance) is accepted and Ha (there is a significant difference between extrovert and introvert students speaking performance) is rejected.

\section{CONCLUSION}

Based on the result of the research toward comparative research of student personality in speaking at Cambridge School of English, some important conclusions can be drawn. The speaking ability of extrovert and introvert students at Cambridge School of English is in a good category with the mean score of extrovert students are 74 and introverts' mean score are 76.53. It is also found that it is no difference between extrovert and introvert students in the class, based on the 
$\mathrm{t}$-count is $-1.360<\mathrm{t}$ table 1.721 . T-table is higher than t-count Ho (Zero Hypothesis) is accepted and $\mathrm{Ha}$ (alternative Hypothesis) is rejected. It can be concluded that there is no difference between students who are extroverts and introverts at Cambridge School of English.

\section{REFERENCES}

Brown, D., H. (2000). Principles of language earning \& teaching. (4thed). New York: Longman

Chen, W. et. al. (2011). A Preliminary Examination of the Relationships among Extroversion-Introversion Personality, Learning Strategies and English Proficiency. Department of Applied English Chaoyang University of Technology.

Child, I., L. (1968). Personality in Culture. In E. Borgatta \& W. W Lambert (Eds.) Handbook of personality theory and research (pp.80-101). Chicago: Rand McNally

Cohen, L., Manion, L., \& Morrison, K. (2007). Research Methods in. Education (6th ed.). London, New York: Routllege Falmer

Eysenck, H. J. (1964). Manual of the Eysenck personality scales. London: Hodder \& Stoughton.

Jung, C. G. (1971). Psychological types (Collected works of C. G. Jung, volume 6, Chapter X)

Nadiyah. (2010). Comparative Analysis on Choleric Students and Melancholic Students concerning Their EnglishSpeaking Skill. Thesis. Department of English Education. Syafir Hidayatullah State Islamic University.

Naiman, N., Frohlich, M. \& Todesco, A. (1978). The good language learner. Toronto: Ontario Institute for Studies in Education

Peterson, C. (1992). Personality. New York: Harcourt Brace Jovanich

Swain, M. \& Burnaby, B. (1976). Personality characteristics and second language learning in young children. Working papers on bilingualism,11, 76-90. Access on June 102021 from http://dx.doi.org

Tuan, N. H., \& Mai, T. N. (2015). Factors Affecting Students ${ }^{\text {ee }} \quad$ Speaking
Performance at LE ThanhHien High School.Asian Journal of Educational Research, 3(2), 8-23.

Vogel, K., \& Vogel, S. (1986). L'interlangue et la personnalite de l'apprenant' [Interlanguage and the personality of the learner]. IRAL. International Journal of Applied Linguistics, 24(1), 48-68.

Wright, D. \& Taylor, A. (1970). Introducing psychology. Harmondsworth: Penguin Books.

Wulandari, D. S. et. al. (2017) Extrovert and introvert students in speaking ability of English Department at IAIN Palangka Raya. Undergraduate thesis, IAIN Palangka Raya. 